\title{
ALITATIVE INDEXES OF SEEDS OF LENTIL VARIETIES
}

\author{
Feruza Yusupzhanovna Khamidova \\ Independent Researcher, Assistant of Department Storage and Processing of Agricultural Products, \\ Tashkent State Agrarian University, Tashkent, Uzbekistan
}

Article DOI: https://doi.org/10.36713/epra3928

\begin{abstract}
The article presents the results of investigations on qualitative indexes of seeds of lentil varieties which is considered one of important crop types for food security.

The influence of cultivation technology and agrotechnical measures on the quality of lentil grains has been studied. Local varieties of lentil "Oltin don", "Darmon" and "Sarbon" varieties were chosen for experiments and whenever their physical-chemical content was analyzed, their seed moisture constituted 8,37-8,59\%, ash amount made 3,10-3,17\% and protein amount showed $22,2-25,4 \%$.

Moreover, there have been stated about the dependence of products quality on the parameters and also the influence of cultivation technology and applied agrotechnics on the quality of grains. Qualitative indexes of local varieties of lentil "Oltin don", "Darmon" and "Sarbon" have been noted as correspondable to requirements. The impact of physical structure on qualitative indexes of lentil grains and chemical content of grains have been noted too. After maturation the study of lentil grains in special grain processing facilities under standard requirements has been highlighted too.
\end{abstract}

KEYWORDS: Lentil, protein, standard, carbohydrate, vitamin, product.

\section{INTRODUCTION}

The seeds of grain-legumes are divided into three groups by their chemical contents - 1) grains rich in starch ; 2) grains rich in protein; 3) grains rich in oil.

The grains with seeds contained average $70-80$ percent carbohydrate and $10-15$ percent protein include to the first group. This group mainly encompasses cereals and buckwheat family crops. Legumes (leguminous crops) comprise the second group and contain $25-40$ percent protein and $50-60$ percent carbohydrate. The third group includes seed oil crops. Their fruits and seeds are rich in oil of average $25-30$ $\%$ and $20-40 \%$ protein too, as well as, there exist several plant families like compositicolous, cruciferous, and leguminous which their fruit and seeds are rich in oil $[1,3]$

It should be emphasized that mostly chemical content of grain is paid attention to in order to determine grain variety, suitability for planting and nutrient properties. Therefore, the words and terms on plant science and botany are widely used for evaluation of nutrient value of grain, commodity research, and product processing.
Not all crops of grain-leguminous group are considered grain producing crops, mostly they are used for meals with coats, particularly, in Uzbek cuisine these grains are used directly. Furthermore, in Uzbek cuisine legumes, such as mung bean, peas, soybean and beans are of great importance and need. Such kind of legumes are often found in daily life and in plots of Uzbek people. The reason for this can be explained that it is known the seeds of legumes contain high amount of protein which can provide human body with important irreplaceable amino acids. Their protein amount is 2-4 times higher than grains (wheat, corn, rice) that constitutes $27-40 \%$ protein $[1,2]$

Due to abundant protein in the content of the seeds of legumes, their value is appreciated highly as food product. Particularly, lentil grain features with its grain content of high starch, for example, soybean grain contains $40 \%$ of protein, $25 \%$ of oil, while in lentil grain the amount of oil is less but starch amount is high and that's why it takes a particular place among food products [3].

Lentil seeds are cooked sometimes directly as a meal and sometimes used in processed form by removing seed coats. Coat removed seeds are also 


\section{EPRA International Journal of Research and Development (IJRD) Volume: 5 | Issue: 1 | January 2020 \\ - Peer Reviewed Journal}

processed again in order to produce flour and groats products. In food industry of some countries lentil grain serves as raw material for the production of canned products. As well as green peas and soybean grain can be widely used in canning industry.

\section{MATERIALS AND METHODS}

Field experiments of the research on lentil growing were carried out during 2015-2018 in "Center of innovative programs and information in agriculture" SUC (State Unitary Company) at Tashkent state agrarian university (TashSAU) and in the fields of the farms "Yangiyul agro product" and "Khanifa Mardieva dalalari" in Jomboy district of Samarkand region.

As an object of the research lentil varieties "Oltin don", "Darmon" and "Sarbon" were chosen. For the cultivation of lentil crop common agrotechnical measures were used [1].

The second stage of the research on the study of chemical content of grain and analysis of its qualitative indexes was implemented in Plant matters chemistry institute under the name of S.Yu.Yunusov at Science Academy of the Republic of Uzbekistan by the method of Yermakov A.I (Methods for biochemical research of plants), chemical content of lentil grain, i.e qualitative indexes of grain, physical indicators, its impurity level and moisture were analyzed with the help of common determiners.

\section{RESULTS AND DISCUSSION}

Qualitative indexes of grain. After maturation the grains of lentil are processed in special grain handling plants according to standard requirements by cleaning seeds, drying and classifying into varieties by size. Some parts of lentil grains are sent to another grain processing center to reprocess the seeds for the production of groats, flour and other products. Sometimes, lentil seeds are directly well-packed instead of processing and delivered to market as food product for consumers. In this case all requirements for lentil grain should be performed according to standard basis. Because whenever lentil grains or groats are delivered to markets and then to consumers, there are some requirements for their quality: the seeds should be recently harvested, with the same color, size, dry or in medium dryness, not infected with pests, cleaned and pure.

Physical indexes. It is important to check and test the sizes, fineness and cleanliness of lentil seeds, because standard requirements demand these measures. For the evaluation of qualitative indexes of lentil grains their color, size, weight, moisture, damage by grain beetle, grain weevil and other pests are considered thoroughly.

The colour of the seed shows when lentil grain is harvested, to which variety it belong and its maturation level too. The colour is an important sign that can determine the consumption value of seed lot. Most lentil seeds are of green, orange, black, brown and paleyellow colours. Small-sized lentil seeds are cooked fast and easily, for example, yellow, orange and black smallsized French lentil seeds are cooked fast as soon as they are put into the pot. Because their coat is thin that allow them to be prepared fast. Thus, if the grain coat is thin, it contains plenty amount of nutrient matters and prepared fast when boiled, cooked grains maintain their whole form without squeeze, the view and taste of meal from lentil are well enough.

The same colour of lentil seeds testifies that they belong to the same variety. The seeds which belong to one variety have the same quality after processing. Therefore, it is required to take into consideration the colour of lentil seeds to be the same, because if their colour is different, it can be easily noted and also their quality is not considered high. As well as the cost of this kind of grain will be low.

Impurity of grain. Like all leguminous crop seeds, lentil seeds are also transported directly from grain handling plant to markets without processing (cleaning). Thus, various mixtures in the seeds of lentil can be added directly to the meal that is prepared from lentil. That's why the seeds processed in grain handling plants should be clean, the mixtures fractions are easily removed from legumes if there is size difference and weight difference between seed and mixtures. For example, green pea seeds are differentiated from green lentil seeds with difficulties, because both of them are of green colour. As well as, it is not easy to separate mung bean from green lentil seeds due to their similar colours. According standard requirements, it is allowed to have 1 $\%$ mung bean and green pea seeds among $99 \%$ pure lentil seeds. But the seeds of weeds and other mixtures are not allowed to be among lentil seeds. Germinability level of $95 \%$ is permitted according to standard, sometimes when lentil seeds are kept for germination, the requirement is to be $95 \%$.

Moisture. The moisture of legume seeds are allowed to be higher than the moisture of cereal (grain) seeds. Because too much dryness of leguminous seeds cause difficulties in cooking, some seeds divide into two halves or may squeeze. Moisture of $14-15 \%$ is required for lentil by standard. Plate-like lentil varieties are to be of $14 \%$ moisture, not more than this, mean moisture from $14 \%$ to $17 \%$ is required for lentil seeds and a bit wet lentil seeds are allowed to be of moisture amount from $17 \%$ to $19 \%$.

When the moisture of grains of lentil varieties was analyzed in our experiments, it showed $8,37 \%$ in Oltin don variety, while in Darmon variety this indicator was $8,59 \%$. 


\section{EPRA International Journal of Research and Development (IJRD)}

Volume: 5 | Issue: 1 | January 2020

- Peer Reviewed Journal

Table-1

Results of moisture amount in the grains of lentil varieties

(Plant matters chemistry institute under the name of S.Yu.Yunusov)

\begin{tabular}{|c|c|c|c|c|c|}
\hline Variety & $\begin{array}{c}\text { Weight of sample } \\
\text { bottle, } g\end{array}$ & $\begin{array}{c}\text { Primary weight of } \\
\text { sample bottle, }\end{array}$ & Sample, $\mathbf{g}$ & $\begin{array}{c}\text { Weighed sample } \\
\text { after drying }\end{array}$ & $\begin{array}{c}\text { Dry matter, } \\
\%\end{array}$ \\
\hline Oltin don & 15,023 & 15,024 & 1,254 & 16,172 & 8,37 \\
\hline Darmon & 12,768 & 14,245 & 1,477 & 14,118 & 8,59 \\
\hline Sarbon & 12,951 & 12,951 & 1,500 & 14,200 & 8,70 \\
\hline
\end{tabular}

Table-2

Physical-chemical analyses of lentil varieties

(Plant matters chemistry institute under the name of S.Yu.Yunusov)

\begin{tabular}{|l|l|c|c|c|c|}
\hline № & \multicolumn{1}{|c|}{ Varieties } & $\begin{array}{c}\text { Moisture, } \\
\text { \% }\end{array}$ & $\begin{array}{c}\text { Ash, } \\
\text { \% }\end{array}$ & $\begin{array}{c}\text { Nitrogen, } \\
\text { \% }\end{array}$ & $\begin{array}{c}\text { Protein, } \\
\text { \% }\end{array}$ \\
\hline $\mathbf{1}$ & Oltin don & 8,37 & 3,17 & 3,64 & 22,8 \\
\hline $\mathbf{2}$ & Darmon & 8,59 & 3,10 & 3,55 & 22,2 \\
\hline $\mathbf{3}$ & Sarbon & 8,58 & 3,11 & 3,58 & 25,4 \\
\hline
\end{tabular}

A Next experiments were on the study of physicalchemical analysis of lentil varieties (table-2). The moisture, ash and protein amount indicators in "Oltin don", "Darmon" and "Sarbon" lentil varieties were close to each other, as moisture level in Oltin don variety grains constituted $8,37 \%$, ash amount $3,17 \%$, protein amount made $22,8 \%$, while in Sarbon variety these indications were $8,58 \%, 3,11 \%$ and $25,4 \%$ relatively. According to table it is obvious that the highest index on protein amount was noted in Sarbon variety, $25,4 \%$ (table-2).

The same size of seeds. The weight and sizes of seeds of legumes are noted to be different. Some varieties have large seeds while some feature with small-sized seeds. Even lentil is divided into large-seed type and small-seed types. Some of lentil grain have thick coat while some feature with thin coat. Thick or thin coat of grains show the nutrient amount in their content.

It is obvious that the seeds of the same size are prepared at the same time, but when they have different sizes these grains cannot be cooked simultaneously, by this case the product quality loses the value in processing industry. When the seeds of different size are not cooked simultaneouly in the meal, it may affect to the taste of the meal and result in difficult digestion process.

Large-seed lentil (macrosperma) stalk height is of $40-75 \mathrm{~cm}$, pods are $1,5-2,0 \mathrm{~cm}$, seed length is $1,0-1,2$ $\mathrm{cm}$, diameter of large seeds is 6-9 mm. Mass of 1000 seeds of large-seed lentil varies from $40 \mathrm{~g}$ to $80 \mathrm{~g}$.

Small-seed lentil (microsperma) stalk height is much lower, 20-50 cm, seed length makes 0,6-0,8 mm and diameter is 3-6 mm. Mass of 1000 pieces of grain varies from $15 \mathrm{~g}$ to $40 \mathrm{~g}$. Most varieties of small-seed lentil are regarded fast prepared type. The reason of the cultivation of large-seed lentil varieties as food product is its high productivity. However, small-sized lentil varieties can have preference over large-seed lentil varieties because of their high protein content, also they require less time to be prepared than other lentil varieties.

\section{CONCLUSION}

Consequently, it can be stated that qualitative indexes of lentil grain are not studied depending on single indication. It is obvious from our investigations conducted on several varieties of lentil, the coat of lentil seeds depend on nutrition regime of lentil and applied agrotechnics. It was determined that qualitative indexes depended on mechanical and physical parameters too in our experiments. The larger size of seeds showed the more dry matter in the content, but the less protein amount.

Chemical content of coats of grain is also important for consumption. Lentil seeds coat is thinner than other legumes which makes $5-10 \%$ of grain mass. Chemical content of lentil seed is similar to pea seeds, but lentil contains more protein (average 2-3\%) and less cellular tissue. Different mixtures among lentil seeds reduce oil yield causing low quality, affecting negatively to seed storage. Much oil amount in seed content allows to fast destroying of quality. Therefore, less oil amount in lentil seeds shows high value of lentil grain as leguminous grain. It can be also concluded that less amount of oil in lentil content allows to store the grains for a long time. 


\section{REFERENCES}

1. Atabaeva Kh.Kh., Kodirkhujaev O. "Plant science", Yangi asr, 2005. 45 p.

2. Yermakov A.I., Arasimovich V.V. 1982. Book: Methods for biochemical research of plant. Moscow, $430 \mathrm{p}$.

3. Kochetov G.A. Practical manual on enzymology. Moscow, 1980. 272 p.

4. Manual on research methods for technochemical control and recording of production in oil manufacture, II edit., Leningrad. 1965. pp. 152-155.

5. Mashkovsky G.F, Babayan M.D., 1989. Spectrophotometrical method for protein determination. Book: State Pharmakopeya USSR. Moscow., 392 p. 